\title{
KEPEMIMPINAN TRANSFORMASIONAL DI LEMBAGA PENDIDIKAN ISLAM
}

\author{
Nuurun Nahdiyyah KY1, Binti Maunah ${ }^{2}$ \\ ${ }^{12}$ UIN Sayyid Ali Rahmatullah \\ Nahdiyah.ponorogo18@gmail.com
}

\begin{abstract}
Changes in times move so fast, all lines of life are required to be able to move with the flow of time. Change demands that all lines of life, including the educational space, can answer the complexity of the problems that arise from the effects of change. This paper focuses on discussing the definition of transformational leadership in Islamic educational institutions, and the implementation of transformational leadership in Islamic educational institutions. the method used is to use a literature review, by taking an inventory of the literature that has the same data needed, and then an analysis is carried out by correlating several educational institutions that are the focus of case analysis. The results of these six studies show that Transformational Leadership is implemented in Islamic education institutions, both in Islamic boarding schools and madrasas, and provides significant results in efforts to improve the quality of education. Implementation efforts carried out in five educational institutions have the same pattern, it is proven that Islamic educational institutions that implement leadership actualize the four main dimensions of transformational leadership. This has been proven to have been carried out at MI Maarif NU Pageruji, the heads of MTsN throughout the city of Kediri, MTsN 2 Medan, MTsN South Jakarta, and MI Maarif Depok Sleman. While one leadership has a different characteristic, namely the transformational leadership of the kyai in the pesantren, this is different from the other five institutions, because the Kyai in the pesantren has an inherent charisma, which the other five leaderships do not have.
\end{abstract}

Keywords; Transformational leadership; Islamic educational

\section{PENDAHULUAN}

Perubahan zaman bergerak begitu cepat, segala lini kehidupan dituntut untuk bisa bergerak mengikuti arus zaman. Perubahan menuntut seluruh lini kehidupan termasuk ruang pendidikan bisa menjawab kompleksitas persoalan yang muncul dari efek perubahan. Pendidikan berkualitas akan menjadi pilihan para pelanggannya untuk menetapkan tempat ruang dialektika ilmu ini tercipta. Mutu pendidikan yang tinggi tentu selalu diawali dari pengelolaan manajemen yang berkualitas, dan di kelola oleh seorang pemimpin yang visioner, transformatif dan inovatif.

Era Disruptif mendorong perubahan paradigma kepemimpinan dalam sebuah organisasi maupun industri, termasuk di dalamnya paradigma kepemimpinan dalam pendidikan. Perubahan yang begitu cepat, mendorong semua lini harus bergerak cepat mengikuti perubahan tersebut. Berangkat dari hal tersebut, pemaknaan terhadap pengertian dasar kepemimpinan telah mengalami pergeseran dan perubahan. Perubahan itu dimulai pada abad ke-20 karena perubahan paradigma, juga pada pemahaman tentang esensi dan makna dunia bisnis dan kerja. Sebelumnya orang lebih memandang implementasi gaya kepemimpinan seorang pemimin, namun saat ini orang lebih melihat pada efektifitas dan efisiensi pengaruh kepemimpinan pada peningkatan mutu baik vertikal maupun horizontal di antara anggota suatu organisasi, komunitas kerja atau usaha (Rafiudin, 2015).

Rendahnya mutu Pendidikan di Indonesia juga tercermin dari daya saing di tingkat nasional bahkan Internasional. Hasil survey PISA (Programme for International Student Assessment) tahun 2018 yang diterbitkan Maret 2019 menyebutkan bahwa Indonesia berada pada urutan ke-74 dari 79 negara dalam hal kompetensi literasi, sains, dan matematika (Sahara, 2019). Salah satu penyebab rendahnya mutu pendidikan di Indonesia adalah terdapat beberapa komponen, diantaranya: pengelolaan, pembiayaan, tenaga pendidik, dan tenaga kependidikan. 
Sebagai contoh motivasi kepala sekolah dan motivasi kerja guru. Hal ini dapat dilihat dari indikasi guru dalam mengoptimalkan perannya sebagai seorang guru, dimana motivasi kerja guru sangat dipengaruhi oleh motivasi kepala sekolah. Oleh sebab itu seorang pemimpin pendidikan memiliki tugas cukup kompleks yang harus dijalankan dan dipahami secara matang sehingga tujuan akan tercapai.

Institusi pendidikan Islam merupakan suatu simbol penggerak perubahan peradaban Islam. Peradaban Islam sejak zaman Rasulullah SAW dibangun di atas peraturan-peraturan samawi yang dititahkan dalam bentuk Al-Quran dan Al-Hadis. Al-Quran sebagai the mother of pardigm memiliki kekuasaan yang tidak bisa diganggu gugat, memiliki aturan yang komprehensif untuk kehidupan manusia terlebih bagaimana interaksi antar sesama yang dinahkodai oleh seorang pemimpin (Mardi, 2009). Rasulullah telah meneladankan melalui hadis dan sunahnya yang sudah banyak dibukukan dan di-syarah-kan oleh para ulama hadis.

Institusi pendidikan Islam saat ini masih dipandang sebagian, perlu upaya keras untuk bisa beradaptasi dengan perubahan karena masih menggunakan pola tradisional. Terbukti dari hasil akreditasi 50\% madrasah memperoleh peringkat B pada tahun 2020. Output yang dihasilkan oleh institusi pendidikan Islam, baik itu siswa maupun mahasiswa belum berbanding lurus dengan kebutuhan lapangan kerja. Hal tersebut disebabkan karena proses yang mereka dapatkan tidak sesuai dengan kebutuhan pasar pekerjaan.

Mutu pendidikan tidak bisa lepas dari kualitas pemimpin sebagai pemegang utama sebuah lembaga pendidikan. Keberadaan pemimpin memberikan kontribusi yang cukup besar terhadap kualitas institusi pendidikan. Modernitas menuntut hadirnya pemimpin yang visioner dan transformatif, sehingga akan muncul sebuah pengelolaan yang baik dan elegan sesuai kebutuhan zaman. Pemimpin yang mampu mengelola SDM dengan baik, memberikan motivasi, dan mampu menggerakkan seluruh pengelola mencapai visi pendidikan.

Memandang hal tersebut, penting untuk dikaji lebih dalam implementasi gaya kepemimpinan transformasional dalam lembaga pendidikan Islam, sebagai upaya memberikan kontribusi fikir terhadap peningkatan mutu. Melalui studi kepustakaan penulis akan menghadirkan beberapa fakta empirik untuk menjadi bahan kajian literatur. Adapun tulisan ini fokus pada dua masalah yaitu: pertama, definisi kepemimpinan transformasional di lembaga pendidikan Islam, dan kedua, implementasi kepemimpinan transformasional di lembaga pendidikan Islam.

\section{METODE}

Dalam penelitian ini metode yang digunakan adalah dengan menggunakan kajian literatur, dengan menginventarisasi literatur-literatur yang memiliki kesamaan data yang dibutuhkan. Kemudian, dilakukan analisis dengan mengorelasikan beberapa lembaga pendidikan yang menjadi fokus analisis kasus. Terdapat dua belas jurnal dan artikel yang ditemukan, enam jurnal membahas tentang definisi kepemimpinan transformasional, enam jurnal dan artikel membahas tentang implementasi kepemimpinan trasnformasional di lembaga pendidikan Islam, dan sembilan jurnal membahas tentang manajemen strategis di lembaga pendidikan. 


\section{HASIL DAN PEMBAHASAN}

Dari banyak teori tentang kepemimpinan, sesungguhnya teladan kepemimpinan terbaik adalah pada diri Rasulullah Muhammad SAW, sebagaimana tertuang dalam Al Qur'an surat Al Ahzab ayat 21 yang berbunyi:

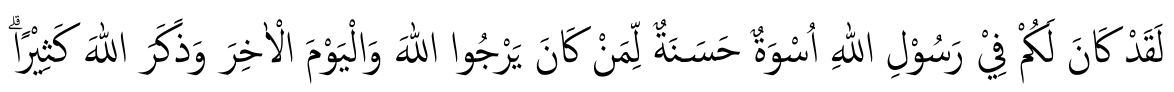

Artinya: Sesungguhnya telah ada pada (diri) Rasulullah itu suri teladan yang baik bagimu (yaitu) bagi orang yang mengharap (rahmat) Allah dan (kedatangan) hari kiamat dan Dia banyak menyebut Allah (QS Al Ahzab ayat 21).

Dalam tafsir Al Misbah karya M Quraish Syihab disebutkan, Kata "uswatun" uswah atau Iswah berarti teladan. Pakar tafsir Zamaakhsyari ketika ayat di atas mengemukakan dua kemungkinan tentang maksud teladan yang terdapat pada diri Rasul itu. Pertama, yang berarti kepribadian beliau secara totalitasnya adalah teladan. Kedua, yang berarti terdapat dalam kepribadian beliau hal-hal yang patut diteladani. Pendapat pertama lebih kuat dan merupakan pilihan banyak ulama. Sedangkan huruf " $f$ " dalam firman-Nya "fi rasuulillah" berfungsi "mengangkat" diri dari Rasul sifat yang hendaknya diteladani, tetapi ternyata yang diangkatnya adalah Rasul SAW sendiri dengan seluruh totalitas beliau, demikian pendapat banyak Ulama. Dalam hal konteks surat ini, saat beliau memimpin perang Khandaq beliau benar - benar menjadi pemimpin yang tangguh, totalitas dalam memimpin, memberikan semangat luar biasa terhadap pasukannya (Shihab, 2002).

Definisi pemimpin menurut Harsey dan Blanchard "seseorang yang mampu memberikan pengaruh pada sekelompok orang untuk mencapai tujuan dari organisasi tersebut (Chaniago, 2017). Definisi lain disebut oleh Morgan (1996), menurutnya pemimpin harus mampu menerapkan tiga hal yaitu: Alighting, menyalakan semangat pengikutnya, Alighning, menggabungkan dua tujuan yaitu tujuan individu dan organisasi, allowing, memberikan keleluasaan pada pengikutnya untuk mengubah dan menantang cara mereka bekerja.

Sedangkan definisi kepemimpinan dikemukakan oleh beberapa tokoh antara lain: Burwash (1996) menyebutkan bahwa kepemimpinan unggul setidaknya memiliki delapan atau sembilan dari dua puluh lima kualitas kepemimpinan terbaik. Indikasi kepemimpinan dengan kualitas terbaik adalah: komitmen, visioner, disiplin tinggi, tidak melakukan kesalahan berulang, antusias, berwawasan luas, kemampuan komunikasi tinggi, mampu memanajemen waktu, bisa mengelola setiap tekanan, mampu menjadi pendidik bagi bawahannya, empati, berfikir positif, spiritualitas tinggi, dan selalu siap melayani. Kepemimpinan unggul setidaknya menetapkan delapan atau sembilan dari komponen sikap tersebut menjadi dasar dalam melakukan tugas kepemimpinanya.

Bennis dan Burt Nanus (1985) memiliki definisi lain soal kepemimpinan, menurutnya kepemimpinan harus memiliki empat kompetensi the ability to manage antara lain: attention (visi), meaning (komunikasi), Trust (kepercayaan atau emotional glue), serta self (komitmen).

Dalam definisi lain Burns, memberikan makna bahwa kepemimpinan transformasional adalah "situasi dimana terjadi proses antara pemimpin dan pengikutnya mencapai tingkat tertinggi dalam hal moralitas dan motivasi, seperti dalam hal menegakkan kemanusiaan, keadilan, 
kemerdekaan, dan bukan didasarkan pada emosi, keserakahan, kecemburan ataupun suka tidak suka Burn, (1997). Pada kepemimpinan trnsformasional akan terus menerus melakukan upaya transforming of visionary dengan melibatkan secara penuh bawahan dalam merumuskan visi dan mencapai visi tersebut.

Berangkat dari definisi kepemimpinan tersebut di atas, maka perlu ditarik pada definisi kepemimpinan transformasional. Ada beberapa tokoh menyebutkan definisi kepemimpinan transformasional antara lain sebagai berikut: Kepemimpinan transformasional mengandung empat dimensi atau empat komponen perilaku, yang disebut dengan 4I antara lain: (Idealized Influence) karisma atau pengaruh yang diidealkan (diberi atribut atau perilaku), (Inspirational Motivation) motivasi inspirasional, (Intellectual Stimulation) stimulasi intelektual, dan (Individual Consideration) pertimbangan individual (Bass, 1985, 1998, Bass \& Avolio, 1993). Syamir, House dan Arthur (1993) dan Conger dan Kanungo (1988) memahami komponen yang sama karena semuanya termasuk dalam kategori kepemimpinan karismatik.

Dalam definisi lain Kepemimpinan yang bersifat transformasional, dapat didefinisikan antara lain: (Idealized Influence) karisma atau pengaruh ideal adalah menetapkan visi, percaya diri, dan menetapkan standar tinggi atau cita-cita ideal untuk dilakukan bersama. Motivasi inspirasionalnya memberikan motivasi pada pengikut dengan keterlibatan penuh dalam mencapai tujuan dan usaha bersama. Stimulasi intelektualnya membantu pengikut untuk mempertanyakan asumsi dan untuk menghasilkan solusi yang lebih kreatif untuk memecahkan masalah. Pertimbangan individualnya memperlakukan setiap pengikut sebagai individu dan memberikan kesempatan pembinaan, pendampingan, dan pertumbuhan (Bass, 1985). Dari definisi tersebut kepemimpinan transformasional seperti itu adalah otentik dan ditandai dengan standar moral dan etika yang tinggi di setiap dimensi tersebut.

\section{Kepemimpinan Transformasional dalam Perspektif Islam}

Untuk mencapai mutu terbaik sebuah organisasi menurut Abduh (2007) dibutuhkan leader yang cerdas, kreatif, mampu menjadi pendidik, pemelihara, seniman, punya inovasi dan antisipatif terhadap tantangan, (rabbul'alamin), yang mengerti kebutuhan anggotanya (rahman) dan selalu mencurahkan kasih sayangnya secara tepat kepada setiap anggota yang memiliki perilaku yang lebih mulia dari yang lainya (rahim). Di samping itu, pemimpin harus mampu mensinergikan dengan tepat antara rabbul'alamin (rasio) dan rahman rahim (rasa) sehingga akan menghasilkan organisasi ideal dan terpuji (alhamdu).

Merujuk dari uraian di atas, dapat pula diambil pengertian bahwa manusia diciptakan oleh Allah sebagai khalifatullah fil arld pemimpin dimuka bumi ini. Sehingga mempunyai tugas kemanusiaan untuk menjadi pemimpin dan bertanggung jawab atas kehidupannya. Sebagaimana termaktub dalam sabda Rasulullah Muhammad SAW :

$$
\text { كلكم راء و كلكم مسأول عن رأيته }
$$

"Setiap kalian adalah pemimpin, dan setiap kalian akan dimintai pertanggungjawaban." 
Sementara dalam sejarah penciptaan manusia diawali dengan penciptaan Nabi Adam a.s, Allah SWT memanggil makhluk-makhluk lain seperti Malaikat dan Jin untuk memberitahukan bahwa akan diciptakan makhluk yang lebih mulia yang menjadi pemimpin di muka bumi:

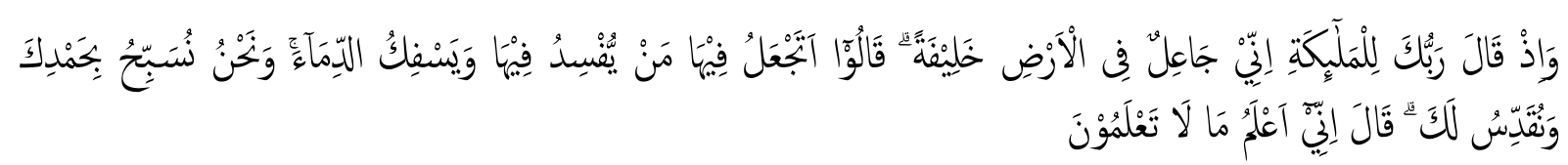

Artinya: "Ingatlah ketika Tuhanmu berfirman kepada para malaikat " sesungghunya Aku hendak menjadikan seorang khalifah di muka bumi". Mereka berkata ;" mengapa engkau hendak menjadikan (khalifah) di bumi itu orang yang akan membuat kerusakan padanya dan menumpahkan darah, padahal kami senantiasa bertasbih dengan memuji Engkau dan mensucikan Engkau? "Allah berfirman; "Sesungguhnya Aku mengetahui apa yang tidak kamu ketahui" (QS.AlBaqarah: 30).

Dalam Tafsir Al Misbah disebutkan bahwa ayat ini merupakan dialog antara Allah SWT dengan malaikat, disampaikan oleh Allah bahwa akan direncanakan penciptaan makhluk di muka bumi dan akan menjadi pemimpin (Shihab, 2000). Perlu dicatat, bahwa kata (خليف) (khalifah) pada mulanya berarti yang menggantikan atau yang datang setelah siapa yang datang sebelumnya. Atas dasar ini, ada yang memahami kata khalifah di sini dalam arti yang menggantikan Allah dalam menegakkan kehendak-Nya dan menerapkan ketetapan-ketetapan-Nya, tetapi bukan karena Allah tidak mampu atau menjadikan manusia berkedudukan sebagai Tuhan. Tidak! Allah bermaksud dengan pengangkatan itu untuk menguji manusia dan memberinya penghormatan. Ada lagi yang memahaminya dalam arti yang menggantikan makhluk lain dalam menghuni bumi ini. Betapapun, ayat ini menunjukkan bahwa kekhalifahan terdiri dari wewenang yang dianugerahkan Allah SWT, makhluk yang diserahi tugas, yakni Adam as. dan anak cucunya, serta wilayah tempat bertugas, yakni bumi yang terhampar ini.

Jika demikian, kekhalifahan memberikan tanggung jawab kepada makhluk yang diberi amanah itu melaksanakan amanahnya sesuai dengan petunjuk Allah yang memberinya tugas dan wewenang. Kebijaksanaan yang tidak sesuai dengan kehendak-Nya adalah pelanggaran terhadap makna dan tugas kekhalifahan.

\section{Lembaga Pendidikan Islam}

Lembaga Pendidikan merupakan lembaga yang menciptakan manusia seutuhnya, sebagaimana yang diketahui bahwa hakikat pendidikan adalah untuk humanisme human (memanusiakan manusia). Dalam prosesnya ruang ini adalah sebuah interaksi yang mewujudkan upaya transfer of knowledge dan transfer of value.

Berbicara tentang lembaga pendidikan Islam tentu akan dihadapkan pada sebuah fakta yang harus terpotret dengan jelas, untuk bisa menetapkan seperti apa idealnya seorang pemimpin dalam menjalankan perannya. Ada beberapa masalah global yang muncul dalam lembaga pendidikan Islam antara lain: ketidakjelasan konsep pendidikan Islam, sehingga muncul dualisme antara pendidikan umum dan pendidikan Islam (madrasah), pendidikan Islam berfungsi sebagai polarisasi budaya dan sosial dari friksi-friksi dan faksi gerakan Islam yang ada, dalam tradisi pembelajaran masih kuat pembelajaran konvensional, kondisi fisik, SDM sangat berbeda dengan 
pendidikan umum, pola kepemimpinan kaku dan tidak memiliki visi merubah atau mentransformasi serta masih banyak institusi yang mengejar kuantitas dari pada kualitas. Hal ini bisa kita temukan di madrasah yang masih kental dengan sistem konvensional, dalam kepemimpinan transformasional kyai di pesantren, peran kyai memberikan dampak pengaruh cukup kuat dengan kharismanya. Hal ini tentu tidak ada dalam sistem kepemimpinan modern.

Berangkat dari deretan masalah yang muncul pada uraian sebelumnya maka lembaga pendidikan Islam sangat membutuhkan pemimpin yang visioner, berkomitmen tinggi, serta memiliki motivasi yang kuat dalam menggerakkan anggotanya menuju visi yang ditetapkan. Tentu fakta mutu pendidikan Islam masih rendah, harus dijawab dengan mengurai masalah tersebut satu-persatu melalui kepemimpinan yang tepat dan efektif.

\section{Implementasi Kepemimpinan Transformasional di Lembaga Pendidikan Islam}

Lembaga Pendidikan Islam secara historis memiliki akar yang cukup kuat. Pengembangan dan pembangunan dilakukan mulai dari yang terkecil secara informal yaitu pengajian-pengajian dari rumah ke rumah, langgar, mushola, atau masjid untuk penguatan kepribadian para penggerak sehingga pada akhirnya dibentuk dalam konsep dakwah yang formal sesuai aturan kenegaraan yang berlaku seperti pondok pesantren, madrasah maupun lembaga perguruan tinggi.

Relevansi gaya kepemimpinan transformasional dalam lembaga pendidikan Islam dapat dilihat dari 4 komponen perilaku atau 4 dimensi yang disebut dengan 4I adalah: idealized influence, Inspiration Motivation, Intellectual stimulation dan individualize consideration.

Berangkat dari 4 komponen ini penulis akan mengambil fakta empirik dari penelusuran penelitian terdahulu untuk melihat bagaimana implementasi kepemimpinan transformasional di lembaga Pendidikan Islam. Adapun beberapa hasil penelitian tersebut adalah sebagai berikut:

Pertama, implementasi kepemimpinan transformasional di MI Ma'arif NU Pageraji Cilongok Banyumas terwujud dalam pola kepemimpinan kepala madrasah yang mampu membangun komunikasi dua arah, yaitu pemimpin dengan bawahan, memberikan motivasi dengan baik, pengelolaan SDM guru dilakukan dengan baik, pelibatan masyarakat dilakukan cukup maksimal sehingga berakibat pada trust masyarakat yang terus meningkat (Maryati, 2017).

Kedua, menunjukkan implementasi kepemimpinan transformasi kyai dalam lembaga pendidikan Islam, menghasilkan temuan Kyai cukup mampu melakukan inovasi terhadap kepemimpinannya dengan kharisma yang cukup kuat juga mampu mengikat komitmen anggota atau pengelola lembaga yang lain (Bashori, 2019).

Ketiga, tulisan yang berjudul Kontribusi Gaya kepemimpinan Transformasional dan Tekad Profesional Kepala Madrasah terhadap Motivasi kerja Guru MTsN 2 Medan, menghasilkan temuan terdapat kontribusi positif terhadap motivasi kerja guru, ditunjukkan dalam nilai korelasi yang cukup tinggi, sebesar $(0,787)$ dan $(0,680)$. Dan ketika gaya kepemimpinan transformasional dikolaborasikan dengan tekad prrofesional kepala madrasah menghasilkan kontribusi sebesar 65,7\% (Sahara Zaini, 2019: 83). Penelitian keempat, dengan judul Pengaruh Gaya Kepemimpinan Transformational terhadap Kepuasan Kerja serta Kinerja Guru Study Kasus MTsN se- Kota Kediri, mengahasilkan temuan antara lain kepemimpinan transformasional yang digambarkan 
responden cukup tinggi, ada pengaruh cukup signifikan antara kepemimpinan transformasional dengan kepuasan kerja, dan menunjukkan semakin tinggi kepuasan kerja semakin semakin tinggi pula kinerja guru (A Badrus H, 2017).

Kelima, dengan judul Kepemimpinan Transformasional Kepala Madrasah, Prestasi Guru, dan Budaya Belajar dalam Meningkatkan Mutu Madrasah Tsanawiyah Negeri Jakarta Selatan, diperoleh temuan Kepemimpinan transfomasional kepala madrasah memiliki peran yang sangat besar, hal ini ditunjukkan melalui hasil koefisien relasi X1 dan Y1 sebesar $=0.487$, temuan selanjutanya kepemimpinan transformasional mampu mendorong peningkatan prestasi guru dan akan berkorelasi dengan peningkatan mutu madrasah (Muhammadi, 2015).

Keenam dengan judul Kepemimpinan Transformational Kepala Madrasah dalam Membangun Karakter Siswa di MI Ma'arif Bego Depok Sleman, menghasilkan temuan kepala MI Maarif Bego telah mengaktualisasikan konsep 4I sebagai dimensi utama pemimpin transformatif hal tersebut adalah Idealized influence dalam membangun karakter, Inspiration motivation terwujud melalui konsistensinya membangun motivasi seluruh anggotanya, Intellectual stimulation diwujudkan dalam pemberian fasilitas untuk meningkatkan SDM seluruh anggotanya, dan Individualize personal ditunjukkan dalam upaya membangun hubungan antar individu, menguatkan tujuan pribadi dengan tujuan organisasi, sehingga tercipta sebuah relasi yang harmonis di lembaga tersebut (Susanto, 2018).

Dari hasil enam penelitian tersebut menunjukkan bahwa Kepemimpinan Transformasional di implementasikan di lembaga Pendidikan Islam, baik di Pesantren maupun madrasah, dan memberikan hasil cukup signifikan dalam upaya peningkatan mutu pendidikan. Upaya implementasi yang dilakukan di lima lembaga pendidikan memiliki kesamaan pola, samasama terbukti sebagai lembaga pendidikan Islam yang mengimplementasikan kepemimpinan dengan mengaktualisasikan empat dimensi utama kepemimpinan transformasional yang telah diterapkan di MI Maarif NU Pageruji, kepala-kepala MTSN se Kota kediri, MTsN 2 Medan, MTsN Jakarta Selatan, dan MI Maarif Depok Sleman. Sedangkan satu kepemimpinan memiliki kekhasan berbeda adalah kepemimpinan transformasional kyai di pesantren, ini berbeda dengan lima lembaga lain, karena Kiai di pesantren memiliki kekuatan kharisma yang melekat, yang tidak dimiki lima kepemimpinan yang lain.

Dari hasil pembahasan tersebut dapat dikerucutkan bahwa kepemimpinan transformasional memberi pengaruh terhadap kinerja, kualitas lembaga, percepatan lembaga mengikuti perubahan zaman, inovasi di berbagai bidang, dan meningkatkan daya saing kelembagaan. Fungsi kepemimpinan transformasional berjalan dengan konsisten pada empat komponen perilaku yang di sebut dengan 4I, antara lain Idealized influence, Inspiration motivation, Intellectual stimulation dan Individual considertion.

\section{KESIMPULAN}

Dari pembahasan tersebut dapat di ambil dua kesimpulan, yaitu: 1) Pemimpin yang unggul melaksanakan setidaknya delapan atau sembilan dari dua puluh lima karakter dasar pemimpin berkualitas antara lain, komitmen tinggi, jujur, visioner, konsisten, inovatif, spiritualtas tinggi, komunikasi baik, karismatik, dan kepemimpinan transformasional. Menurut 
Nanus, Burn, Bernard M Bass pemimpin yang berkualitas ditunjukkan dengan empat komponen perilaku atau disebut dengan empat dimensi (4I) antara lain idealized influence, Inspiration motivation, Intellectual stimulation, dan Individual considertion. Kepemimpinan transformational dalam Islam terdapat dalam teladan Rasulullah dan tercermin dalam beberapa hal: punya inovasi dan antisipatif terhadap tantangan (rabbul'alamin), yang mengerti kebutuhan anggotanya (rahman), dan selalu mencurahkan kasih sayangnya secara tepat kepada setiap anggota yang memiliki perilaku yang lebih mulia dari yang lainya (rahim).

Kedua, kepemimpinan tranformasional yang diimplementasikan dengan baik memberikan dampak cukup signifikan terhadap peningkatan mutu pendidikann di lima lembaga formal antara lain di MI Maarif NU Pageraji, MTsN Jakarta Selatan, Kepala MTSN se Kota Kediri, MTsN 2 Medan dan MI Maarif Depok Sleman. Kepala sekolah di lima lembaga tersebut mampu menginternalisasi empat dimensi utama kepemimpinan transformasional dengan baik. Sedangkan Kyai di pesantren ditunjukkan dengan kekhasannya yang kharismatik mampu mengikat komitmen seluruh anggotanya sehingga mampu menciptakan kualitas lembaga dengan cukup baik.

\section{BIBLIOGRAFI (Cambria 11, Spasi 1.5)}

Bernard M Bass, Paul S. (2006). Ethic, Character, and Autenthic Transformasional Leadership.

(Center for Leadership Studies, School of Management Binghamton University, Binghamton, NY 13902-6015)

Chaniago , Aspizain. (2017). Pemimpin dan Kepemimpinan. Lentera Ilmu Cendekia.

Hartono, Frans Mardi. (2009). Paradigma Baru Manajemen Indonesia, Menciptkan Nilai dengan Bertumpu Pada Kebajikan dan Potensi Insani, (Bandung: Mizan Pustaka )

Basori, Al-Tanzim. (2019). Jurnal Manajemen Pendidikan Islam E-ISSN: 2549-5720 P-ISSN: 2549-

$\begin{array}{lllllll}3663 & \text { Vol. } & 03 & \text { No. } & 02 & \text { 73-84 }\end{array}$

https://ejournal.unuja.ac.id/index.php/al-tanzim

Bass, B.M. (1985). Leadership and performance beyond expectations. New York: Free Press, Jurnal Ilmiah.(2015). Studi Pemikiran Pendidikan Agama Islam Kreatif. Vol. XII No. 1 Januari

Maryati , Solihah. (2017). Kepemimpinan Transformational Kepala Madrasah dalam Meningkatkan Mutu Pendidikan di MI Ma'arif NU Pageraji Kecamatan Cilongok Banyumas. IAIN Purwokerto, TESIS.

Rafiudin. (2015). Konsep dan Impelentasi Gaya Kepemimpinan Transformastiona dalam Institusi Pendidikan Islam. Jurnal Ilmiah "Kreatif". Vol. XII No. 1 Januari Jurnal Studi Pemikiran Pendidikan Agama Islam.

Sahara, Zaini, Kontribusi Gaya Kepemimpinan Transformasional dan Tekad Profesional Kepala Madrasah Terhadap Motivasi Kerja Guru di MTsN 2 Medan, (UIN SUMUT, Tesis 2019) hal.2 Shihab , M. Quraish, (2002)Tafsir Al-Misbah (Jakarta: Lentera Hati,)

Zaini Sahara. (2019). Kontribusi Gaya kepemimpinan Transformasional dan Tekad Profesional Kepala Madrasah terhadap Motivasi kerja Guru MTsN 2 Medan. UIN SUMUT Medan, Tesis. 
Ahmad Badrus Hisbullah. (2017). Pengaruh Gaya kepemimpinan Transformational terhadap Kepuasan Kerja serta Kinerja Guru Study Kasus MTsN se-Kota Kediri. UIN Malang, Tesis.

Nur Muhammadi, Sahril. (2015). Kepemimpinan Transformasional Kepala Madrasah, Prestasi Guru, dan Budaya Belajar dalam Meningkatkan Mutu Madrasah Tsanawiyah Negeri Jakarta Selatan. TARBAWI Volume 1. No. 01, Januari Juni ISSN 2442-8809.

Wawan Hadi Susanto. (2018). Kepemimpinan Transformational Kepala Madrasah dalam Membangun Karakter Siswa di MI Ma'arif Bego Depok Sleman. Jurnal, Nidhomul Haq, Vol 3 No 2. 